\title{
Evaluating the Impact of Different Vegetation Types on NEE: A Case Study of Banni Grasslands, India
}

\author{
Usha Joshi* (), G. Sandhya Kiran (1) \\ RS-GIS and Ecophysiology Lab., Department of Botany, Faculty of Science, The Maharaja Sayajirao University of Baroda, \\ Vadodara, India \\ Email: *ushajosh12@gmail.com
}

How to cite this paper: Joshi, U. and Kiran, G.S. (2021) Evaluating the Impact of Different Vegetation Types on NEE: A Case Study of Banni Grasslands, India. Journal of Environmental Protection, 12, 490-507. https://doi.org/10.4236/jep.2021.127031

Received: June 9, 2021

Accepted: July 24, 2021

Published: July 27, 2021

Copyright () 2021 by author(s) and Scientific Research Publishing Inc. This work is licensed under the Creative Commons Attribution International License (CC BY 4.0).

http://creativecommons.org/licenses/by/4.0/

\section{(c) (i) Open Access}

\begin{abstract}
Estimation of NEE of Grasslands ecosystems becomes mandatory as these grasslands with their wide spread (almost $40 \%$ of land of the earth) and high plant diversity play a major role in global carbon balances and NEE at both local and global scale. The present study has been focused on understanding the role of different plant species responsible for variation in NEE of the Banni Grasslands of India. These grasslands form a belt of arid grassland having low growing forbs, graminoids and scattered tree cover. Due to its wide spread and inaccessibility of Banni, this study utilized spatial approach for evaluating carbon emissions and NEE. Landsat data was utilized for vegetation type classification and SMAP data for extraction of NEE values proved their potential for categorising vegetation type and generating NEE values precisely. Three major plant types were identified from the study area viz., Grasslands, Land with Acacia and Land with Prosopis. Grasses were dominant covering $77 \%$ and the rest of the area was occupied by the other two classes, i.e. Acacia and Prosopis. The NEE values were higher for the grasses when compared to the other two plant species proving to be the active sinks when compared to other plants. The differential contribution of NEE by species has been depicted in the present work.
\end{abstract}

\section{Keywords}

Normalized Difference Vegetation Index (NDVI), Fractional Vegetation Coverage (FVC), $\mathrm{CO}_{2}$ Flux, Prosopis, Grasses, Acacia

\section{Introduction}

Regional and interannual patterns of the terrestrial carbon dynamics are chang- 
ing enormously due to increasing atmospheric $\mathrm{CO}_{2}$ and climate change which makes it imperative to understand the phenomenon at ecosystem level [1] [2] [3]. Estimation of Net Ecosystem $\left(\mathrm{CO}_{2}\right)$ Exchange (NEE) is an important parameter to understand the carbon dynamics of terrestrial ecosystems as it outlines the net exchange of Carbon (C) occurring between an ecosystem and the atmosphere (per unit ground area) [4] [5] [6] [7]. It is crucial in determining the role of these ecosystems in regional and global C balances. Grasslands are one of the important terrestrial ecosystems which play a significant role in $\mathrm{NEE}$ of $\mathrm{CO}_{2}$ at both local and global scale owing to their wide coverage and high plant diversity [8]. These ecosystems are highly sensitive to precipitation variability and thus show varied patterns of interannual variations in net primary productivity which shows a direct impact on NEE [9] [10] [11]. Not only that, but NEE is very sensitive to on-going shifts in the plant species composition [12] [13]. Even short-term changes in plant species alter the ecosystem carbon budgets through increased inter and intra-annual variations in NEE by biophysical and biogeochemical pathways [14]. Plant species type is important parameter to be considered while analysing the variations in NEE of the grasslands [15]. It is therefore important to evaluate interactions and feedbacks within the carbon cycle with different plant species [16]. The role of grasslands in NEE has not been adequately quantified specifically in India though it has potential importance and contribution. Therefore, this study has been taken up for the Banni Grasslands located in Kutch, Gujarat, India. These grasslands are one of the largest grasslands of its kind in Asia with high plant diversity which highly influences the global and regional climate. Due to its wide spread and inaccessibility of Banni, this study utilized a spatial approach for evaluating carbon emissions and NEE. As the satellite-based methods have high spatial-temporal resolution even at landscape level, their utilization in measurement of NEE becomes imperative.

Satellite remote sensing continuously measures the carbon fluxes with high temporal and spatial coverage and provides an attractive and powerful tool for upscaling the fluxes. Many ecosystem carbon exchange models have been developed which utilizes remote sensing data to understand the carbon dynamics at the ecosystem level or beyond [17]. Combining NEE data with remote sensing is the most feasible method for mapping carbon sources and sinks for grasslands [18]. Satellite data provides consistent and systematic observations of vegetation and ecosystems, and plays an important role in estimation of NEE [19]. Using remote sensing for NEE measurements avoids problems associated with smallscale flux sampling while determining areas of sink. In earlier years, biomass inventory and soil carbon quantity were utilized to measure an ecosystem NEE over a specific period [20]. In today's time, two main techniques have been developed for measuring NEE fluxes: the Eddy Covariance (EC) technique and the chamber technique. EC technique provides measure the fluxes continuously at ecosystem scales for many seasons and years along with quantifying the impact of various environmental factors on the fluxes [21] [22] [23]. However, this technique provides measurements over tower footprints with relatively smaller areas 
that depend upon the tower height, canopy physical characteristics and wind velocity [24]. This has unveiled the limitations of this technique despite its high temporal resolution [25]. Chamber technique is important for point measurements of NEE, but prone to a variety of potential errors and consumes plenty of time [26] [27] [28]. In addition, it is not possible to scale up net $\mathrm{CO}_{2}$ exchange over the ecosystem level using EC and Chamber techniques [29] [30] [31]. Application of spatial approach can overcome this problem. Spatial approach also aids in understanding the distribution of different plant species of grasslands which helps in precise understanding.

Distribution of different grasses, their association and net primary production of these ecosystems play crucial role in global carbon budget and influence regional climate by modulating the evapotranspiration flux [13]. In this context, distribution and quantification of vegetation become imperative for understanding to encompass the changes in carbon flux. Satellite-based Normalized Differential Vegetation Index (NDVI) helps in comprehensive monitoring and quantification of vegetation [32] [33] [34]. Fractional Vegetation Cover (FVC) which is derived from NDVI using empirical relations is the vegetation-covered fraction of ground [35]. FVC is the ratio of the vertical projection area of vegetation (including leaves, stalks, and branches) on the ground to the total vegetation area which is directly detectable by the sensor from any view direction [36] [37]. FVC measured using spatial approach provides basic data for characterizing ecosystems which plays an extremely crucial role in the study of regional ecosystems [38] [39] [40] [41] [42]. Most importantly, FVC helps in understanding the seasonal changes occurring in the exchange of $\mathrm{CO}_{2}$ between the land surfaces and the atmospheric boundary level [43].

Considering above facts, this study has been taken up to analyse the role of different plant species in variations of NEE to understand the carbon dynamics of Banni grasslands. These ecosystems are very sensitive to future changes in climate, and understanding how these systems have responded to climatic changes in the past can provide us with insights into their potential responses to future global change.

\section{Study Area}

Banni grasslands form a belt of arid grassland ecosystem covering almost 2675 $\mathrm{km}^{2}$ on the outer southern edge of the desert of the marshy salt flats of Rann of Kutch in Kutch District, Gujarat State, India (Figure 1). Similar to other grasslands, vegetation in Banni is sparse and highly dependent on seasonal variations in monsoon. Growing season for grasses starts from the month of June (Onset of monsoon) and lasts up to December month. Banni is dominated by low-growing forbs and graminoids, many of which are halophiles (salt tolerant), as well as scattered tree cover and scrub. The tree cover is consists of Salvadora spp. and the invasive Prosopis juliflora while Cressa cretica, Cyperus spp., Sporobolus, Dichanthium, and Aristida are the dominant species found in the area. 


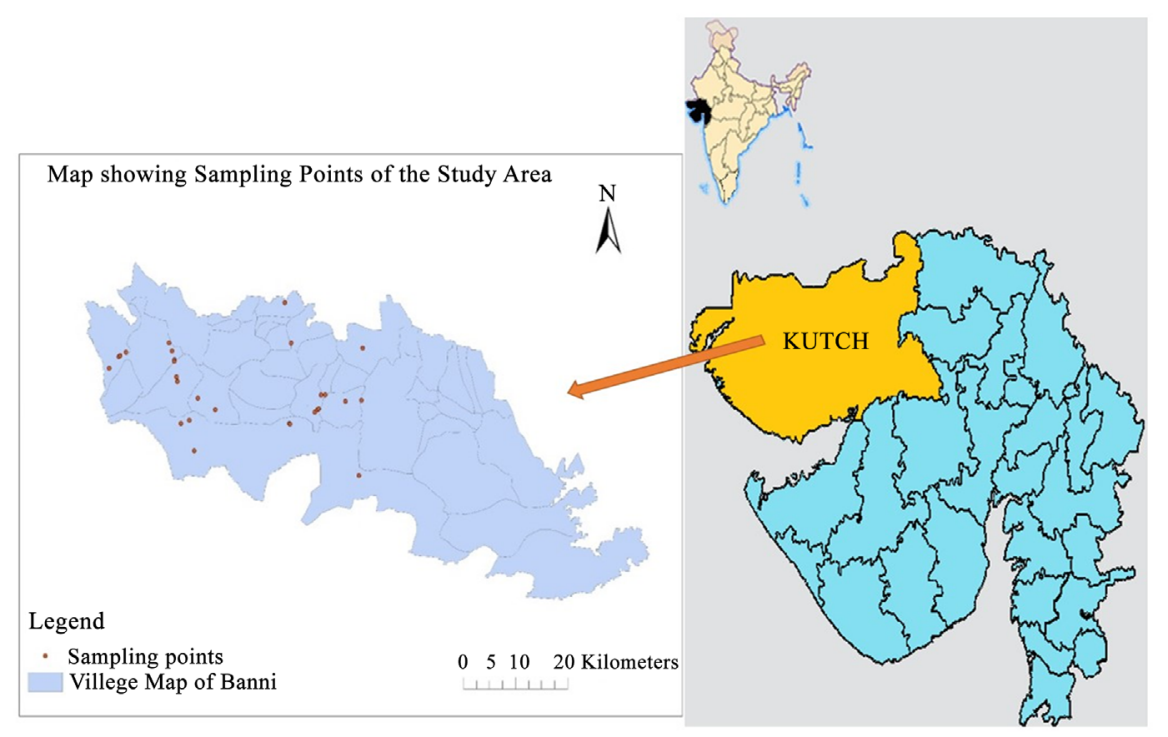

Figure 1. Map showing the sampling points of the study area.

Traditionally, the Banni was declared as a Rakhal (reserve grassland) where only milch cattle were allowed to graze, and sheep and goats were not allowed to reduce the pressure on the grasslands. People were not allowed to reside in the Banni. Later, sheep and goats were also allowed to graze in the area but grazing was regulated by imposing fee at various rates for different categories of livestock. However, this traditional resource management system which had helped in the maintenance of equilibrium between environmental system and human activity since several centuries was no more functional [44]. The grazing regulations slowly disappeared, and all kinds of livestock from every part of the state and neighbouring states were allowed into the area. Large numbers of livestock used to immigrate for grazing during 3 - 4 months of monsoon [45] [46]. Recent interventions such as introduction of $P$. juliflora, introduction of additional livestock have led to reduction in carrying capacity of these grasslands.

\section{Materials and Methods}

\subsection{Pre-Processing the Datasets}

Cloud-free Landsat ETM+ satellite data of Nov. 2017 was acquired from USGS website. The data was geographically corrected and was having geographical projection with WGS 84 datum. The study area was included in two different scenes. These two scenes were stacked separately and then mosaicked together to get the study area. The dataset was having the spatial resolution of $30 \mathrm{~m} \times 30 \mathrm{~m}$.

Daily Soil Moisture Active Passive (SMAP) version 4.0 NEE data from the month of January to December 2017 i.e. for 365 days was acquired from the website (https://nsidc.org/data/smap/data_versions). This data set was having the spatial resolution of $9 \mathrm{~km} \times 9 \mathrm{~km}$. The dataset was having geographical projection with WGS 84 datum. This data was subset for the study area and then stacked month wise for further processing. 


\subsection{Methodology}

The study area was visited frequently for identifying the areas with different plant species. Landsat Enhanced Thematic Mapper Plus (Landsat ETM+) data of Nov. 2017 was utilized for vegetation classification. Normalized difference vegetation index (NDVI) and Fractional Vegetation Cover (FVC) of the study area were generated for November month of the years 2015, 2016 and 2017. Ground Control Points (GCPs) were collected for accurate identification of various species based on which the supervised classification was carried out. Supervised classification was carried out using the maximum likelihood algorithm of Earth Resources Data Analysis System (ERDAS) Imagine 9.1. Three different classes identified using the satellite data which were Land with Prosopis, Land with Acacia and Grasslands. Accuracy assessment of classified out was carried out by validating random points by field visits.

Daily NEE values corresponding to the GCPs corresponding to the different plant species derived by classification (i.e. classes like Grasslands, Land with Prosopis and Land with Acacia) were extracted from the datasets. Extracted values were averaged out monthly in order to understand the seasonal variation in NEE. Cumulative NEE of different classes was also calculated. Maps for different outputs were generated using ArcGIS 10.4 software.

NDVI of the study area was derived from Landsat ETM+ data of Nov. 2017. The study area was classified in the four classes, i.e., No vegetation (values lower than 0), Low vegetation (values between 0.1 and 0.3), Medium Vegetation (values between 0.3 and 0.5 ) and High vegetation (values above 0.5), based on the NDVI values. NDVI was derived using the following formula:

$$
\mathrm{NDVI}=\frac{\mathrm{NIR}-\text { Red }}{\mathrm{NIR}+\text { Red }}
$$

where NIR denotes the near infrared band and Red denotes the red band.

FVC of the study area was derived using NDVI image using the following formula:

$$
\text { FVC }=\frac{\text { NDVI }- \text { NDVIsoil }}{\text { NDVIveg }- \text { NDVIsoil }} \times 100 \%
$$

where NDVI denotes the NDVI value of the pixel, NDVIveg is the NDVI value of a pure green vegetation pixel, and NDVIsoil is the NDVI value of bare soil.

The study area was classified in following 4 different classes based on the fractional vegetation coverage, i.e. Low (lower than $0 \%$ to $25 \%$ ), Medium (25\% to $50 \%$ ), Medium high (50\% to 75\%) and high (higher than 75\%) [47].

\section{Results and Discussion}

Grasslands are amongst the important ecosystems that sequester and store large amounts of soil carbon, which is highly dependent on the factors like herbivory and precipitation. Studies have been attempted to understand effects of different factors on carbon cycling in different regions and how much do they contribute 
to the NEE. The present study focussed on recognising the patterns of net $\mathrm{CO}_{2}$ exchange in the Banni Grassland, the largest native grassland ecosystem in of Kutch region. The study conducted during three contrasting precipitation years (dry vs. wet summer), has allowed to investigate on vegetation types existing in this area and their impact on net $\mathrm{CO}_{2}$ exchange.

Based on Landsat 2017 satellite data classification, three categories classes were identified, viz. Grasslands, land with Acacia and land with Prosopis. Out of three classes generated, Grasslands occupied almost $77 \%$ of the study area and were found to be distributed evenly. The grassland class was occupied by grass species like Dichanthium annulatum (Jinjvo), Cenchrus ciliaris (Dhaman), Sporobolus fertilis (Khevai) and Chloris barbata (Siyarpuchha) and undershrubs like Suaeda maritimum (Lano), Suaeda fruticosa (Untmorar), Suaedanudi flora (Lano), and Tamarix aphylla (Lai). Acacia and Prosopis species occupied 19\% and $4 \%$ of the area respectively, with Acacia occupying the middle part of the study region while Prosopis at the southwestern side (Figure 2 and Figure 3). Classified output showed the accuracy of $85 \%$ with the kappa coefficient of 84.83 . This indicated that the grasslands are still a dominant vegetation type of the study area which can contribute significantly in carbon dynamics. However, woody species like Prosopis and Acacia are slowly encroaching the area under grasslands, further altering the carbon dynamics (49).

Further investigation of vegetation carried out using NDVI and FVC for the three consecutive years confirmed the vegetation categorisation with NDVI and FVC values highest for Grassland followed by Acacia and Prosopis (Figures 4-9). Most of the study area was covered by low vegetation indicating the presence of grasses which showed the FVC value of $60 \%-70 \%$. Higher area occupied

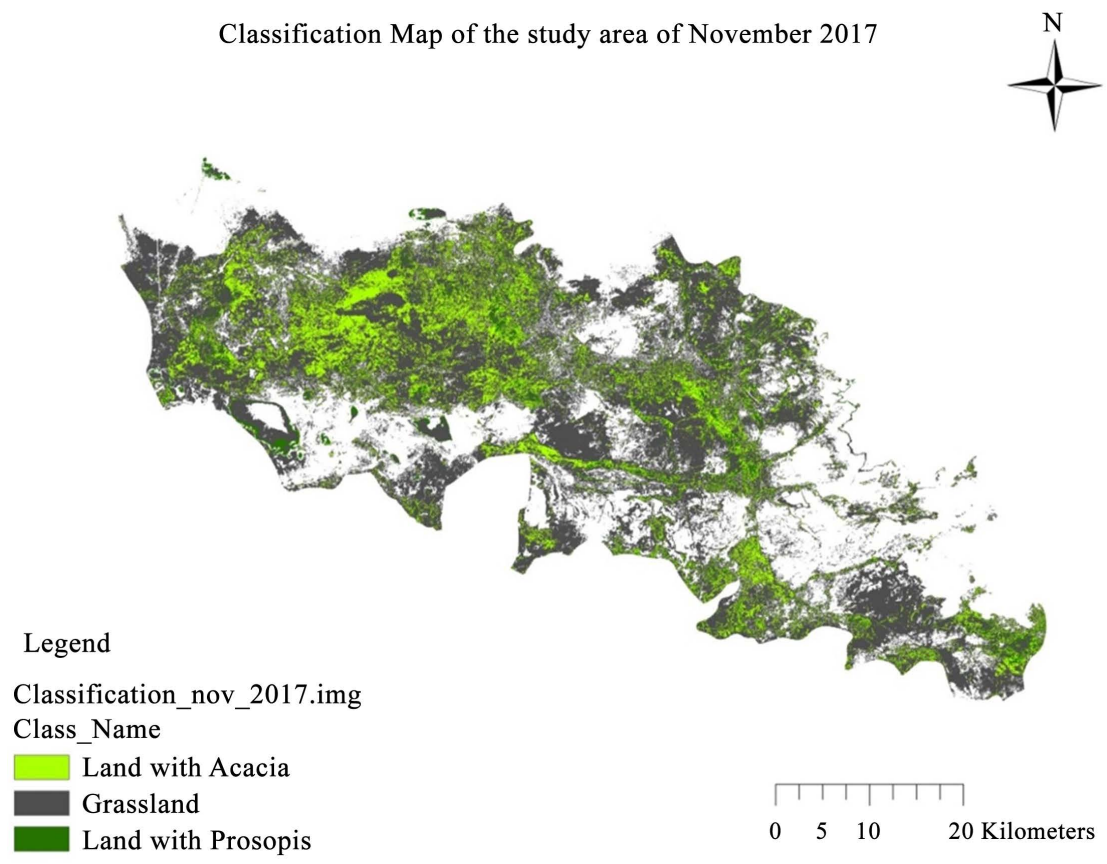

Figure 2. Map showing plant species map of the study area. 


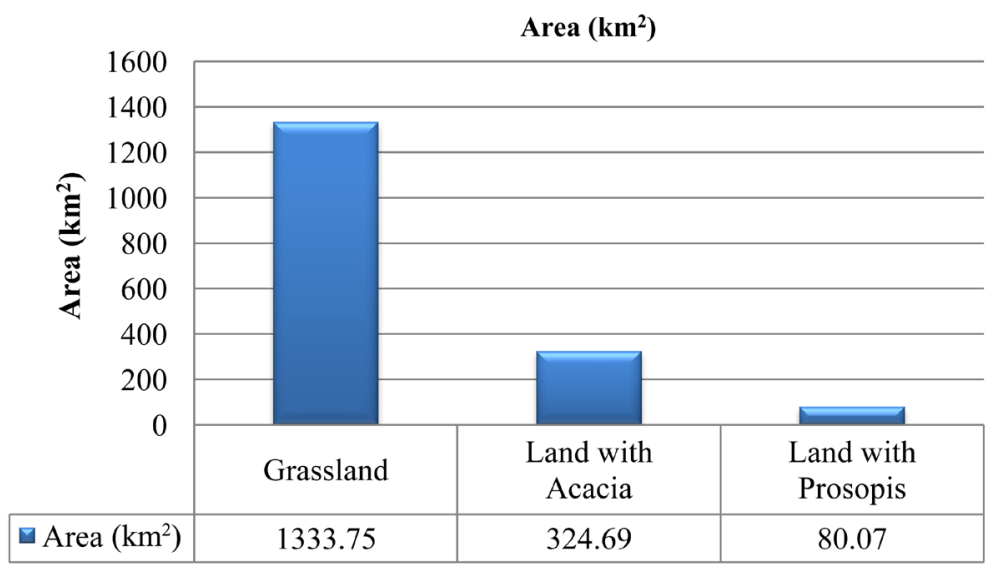

Figure 3. Chart showing the area statistics of Banni grasslands.

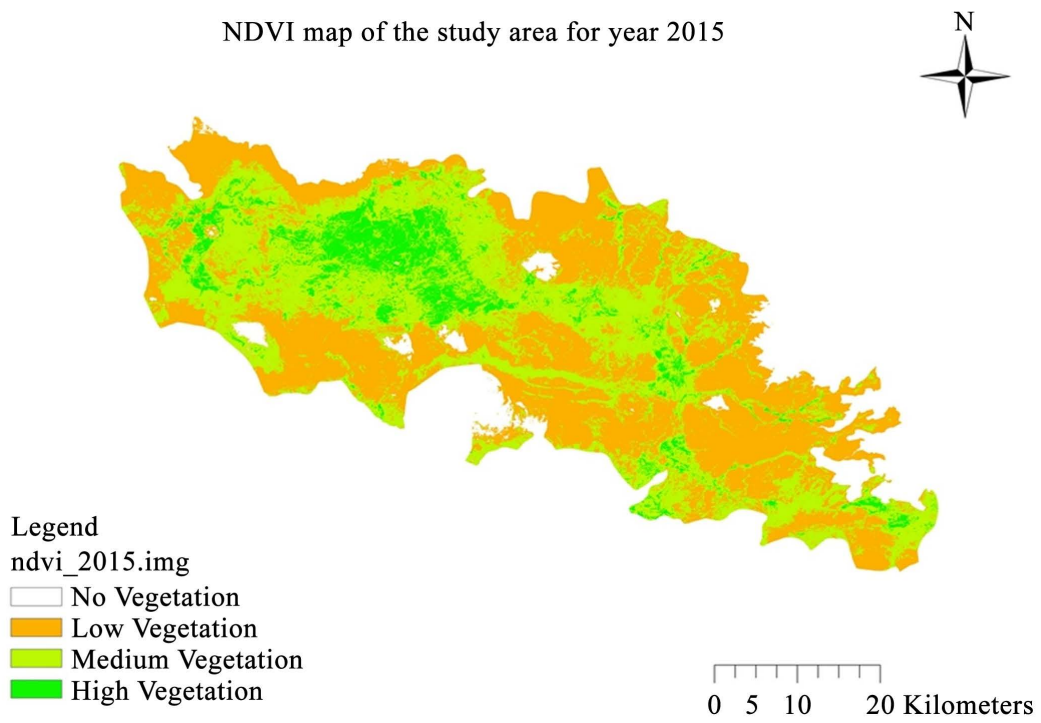

Figure 4. NDVI map of the study area for year 2015.

NDVI map of the study area for year 2016
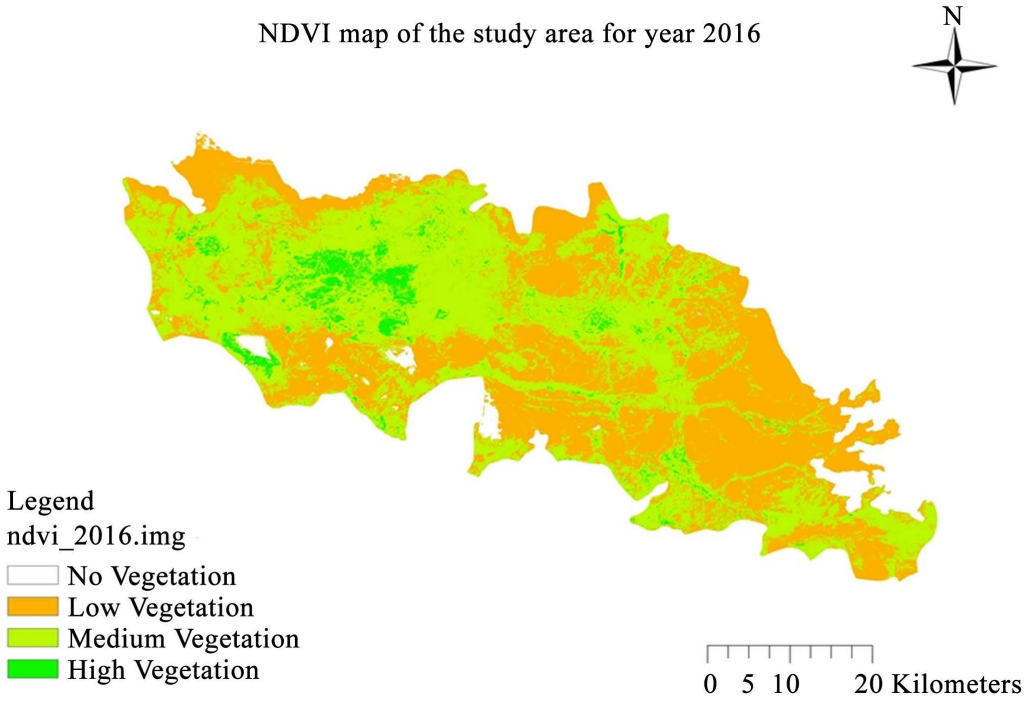

Figure 5. NDVI map of the study area for year 2016. 


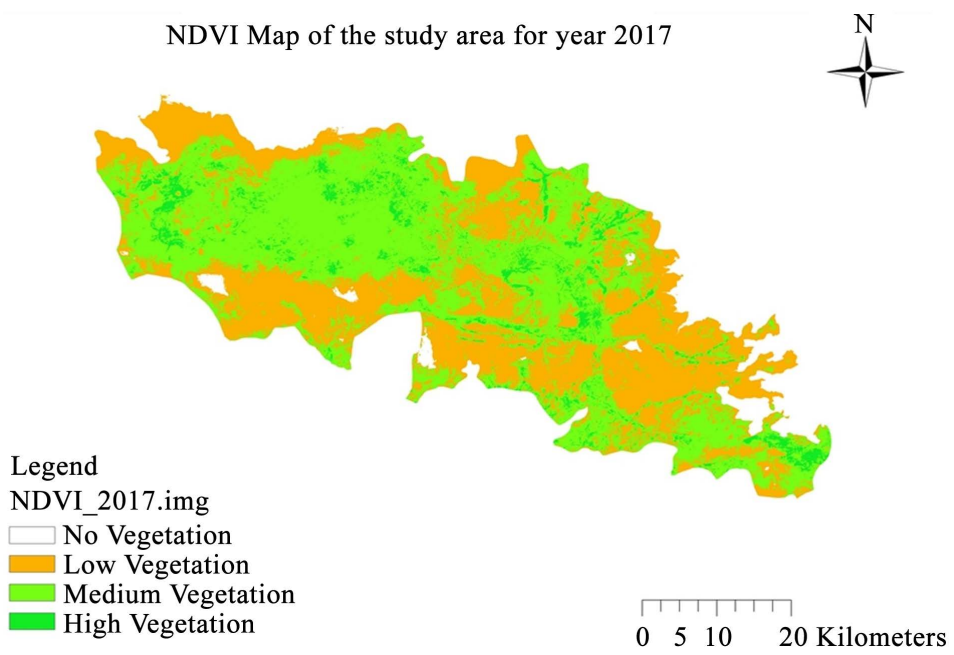

Figure 6. NDVI map of the study area for year 2017.

FVC Map of the study area for year 2015
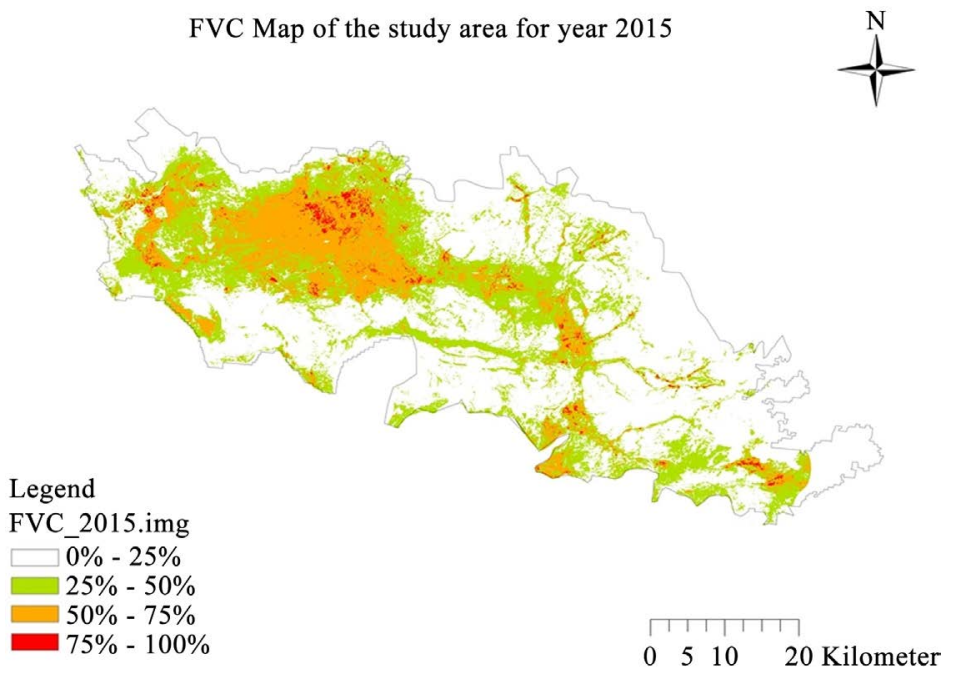

Figure 7. FVC map of the study area for year 2015.

FVC Map of the study area for year 2016
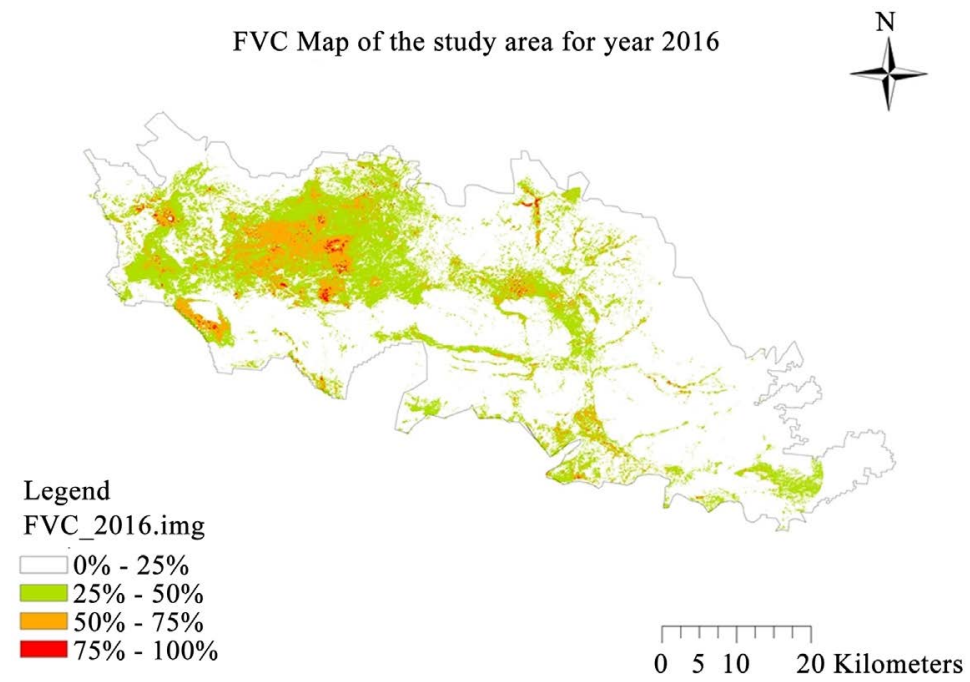

Figure 8. FVC map of the study area for year 2016. 


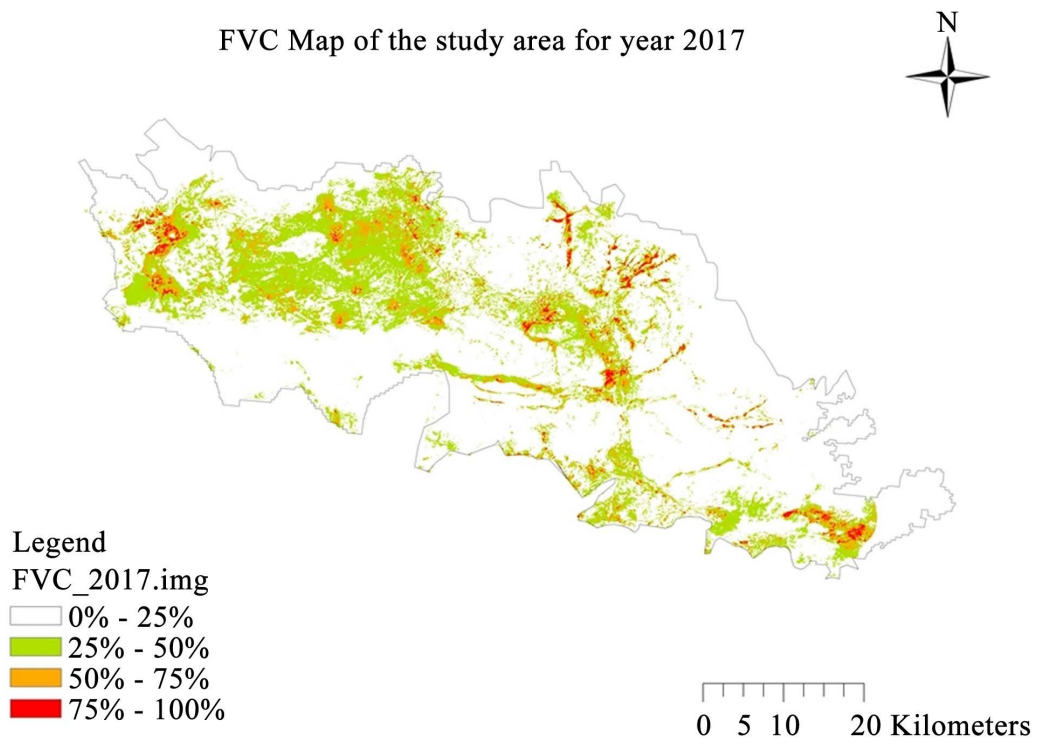

Figure 9. FVC map of the study area for year 2017.

by low vegetation, i.e. sparse grassland revealed the fact that the grasslands are under pressure and getting degraded at a faster rate. NDVI values also revealed the health status of vegetation of the study area because these values were closely related to biomass [48] [49], biomass moisture [50], leaf area index [51] [52], absorption of photosynthetically active radiation [53], trends of photosynthesis and transpiration [54] [55] [56], respiration [57] and $\mathrm{CO}_{2}$ uptake [56] [57].

Clear seasonal variation in NEE was observed, i.e. negative values during the growing period (from Aug. to Nov.) of the grasslands and positive values rest of the year (during Dec. to July) (Figures 10(a)-(c)) [58]. NEE increased steadily with the progress of the growing season and decreased after the peak in the growing season. Seasonal changes in NEE reflected the vegetation phenological development (in monsoon) and seasonal changes in environmental driving forces [59] [60]. The values ranged from $-1.66 \mu \mathrm{g} / \mathrm{m}^{2}$ to $0.66 \mu \mathrm{g} / \mathrm{m}^{2}$ for grasses while it varied from $-1.41 \mu \mathrm{g} / \mathrm{m}^{2}$ to $0.64 \mu \mathrm{g} / \mathrm{m}^{2}$ for Acacia. A negative value of NEE means a net carbon gain by the ecosystem, i.e., positive net ecosystem productivity (NEP), as it may be assumed NEP to equal-NEE [61]. Positive values of the NEE indicated that the ecosystem was acting as a source during these months [62] [63]. The reason being in summer, water deficits caused leaf senescence (herbs) and therefore less assimilation of carbon leading to decrease in Gross Primary Production (GPP) and thus positive NEE. Periods of negative NEE (indicating net ecosystem uptake) were smaller in magnitude and spanned a shorter duration and coincided with the growing period of the grasses (monsoon). Acacia ecosystem varied from a net sink to a carbon source depending on the time of year, with a lower/higher magnitude during the warm/cold season [64].

Yearly comparison of the NDVI, FVC and NEE showed that the NDVI and FVC were higher in the years 2015 and 2016 while the values were lower in the year 2017 (Figures 11-16). However, NEE values were found to be higher in the 


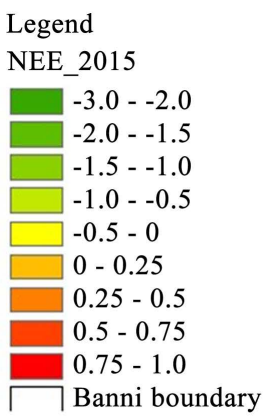

Legend NEE_2016

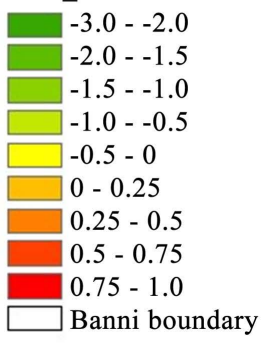

Legend Dec 2017

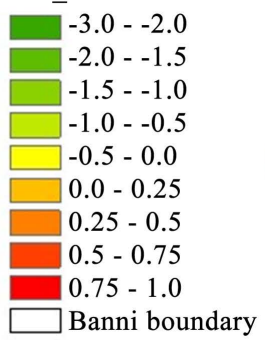

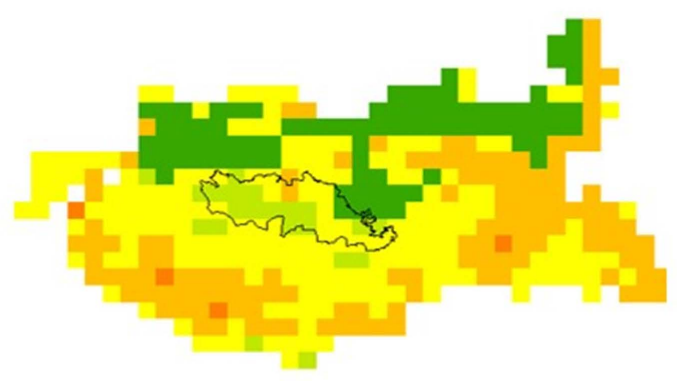

(a)

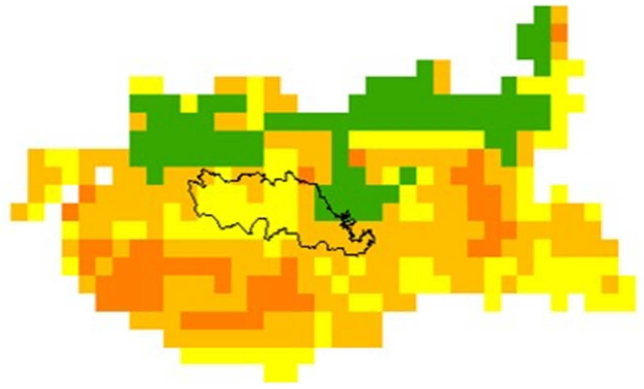

(b)

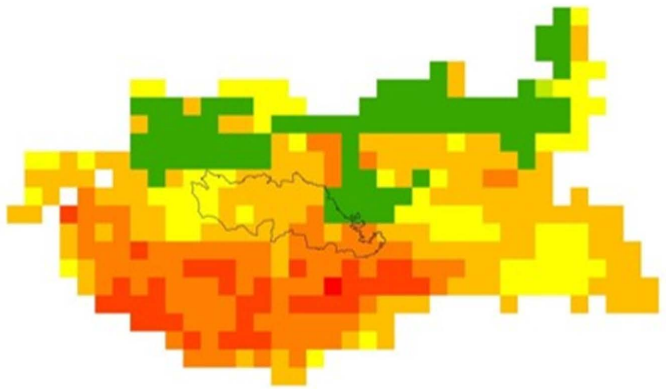

(c)

Figure 10. (a)-(c) Variation observed in NEE between years 2015 to 2017. (a) Map showing NEE of December 2015; (b) Map showing NEE of December 2016; (c) Map showing NEE of December 2017.

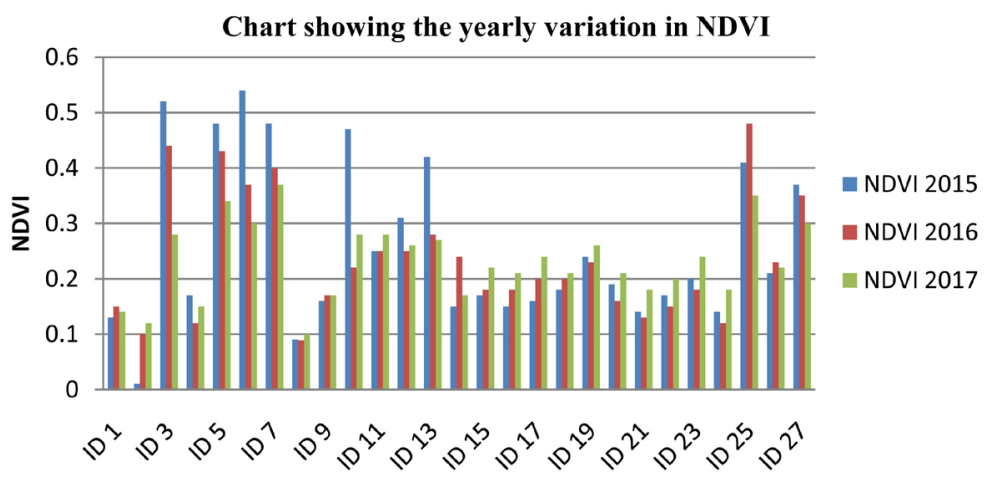

Figure 11. Chart showing the yearly variation in NDVI. 


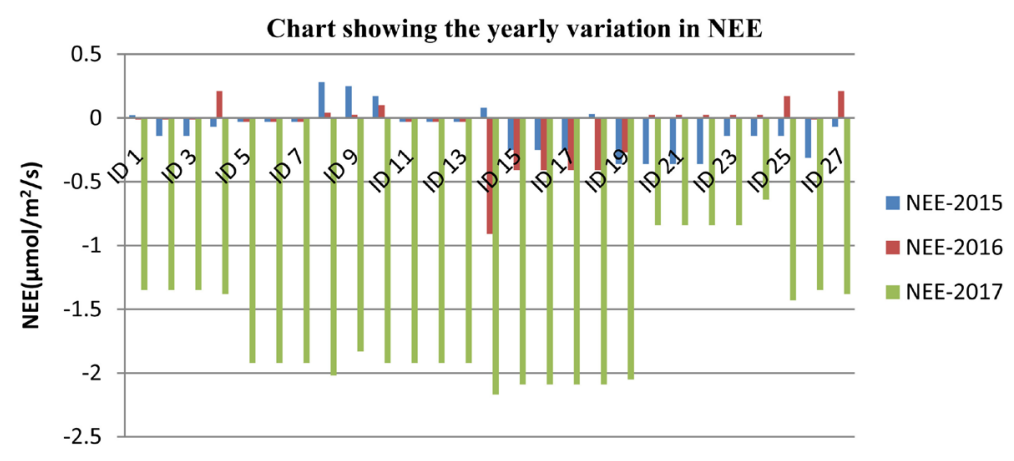

Figure 12. Chart showing the yearly variation in NEE.

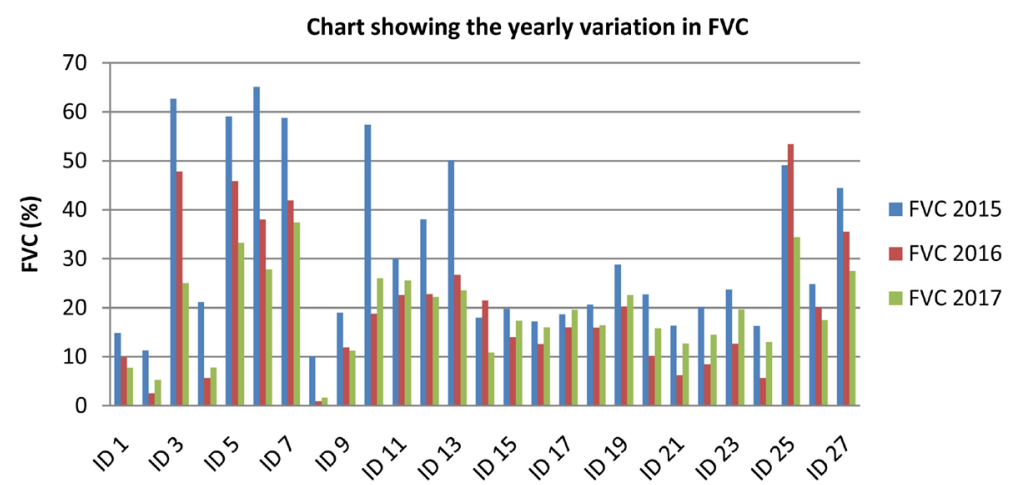

Figure 13. Chart showing the yearly variation in FVC.

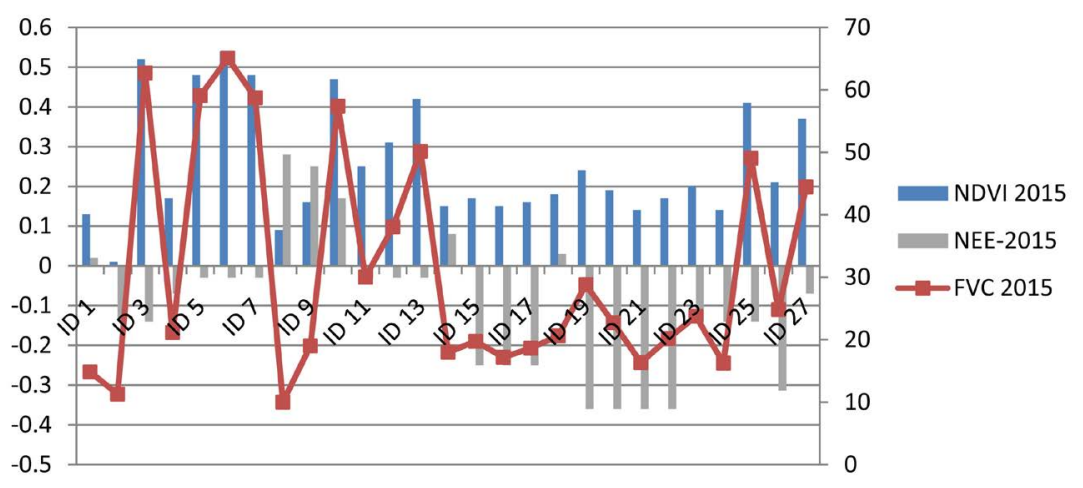

Figure 14. Chart showing comparative account of NDVI, FVC and NEE for year 2015.

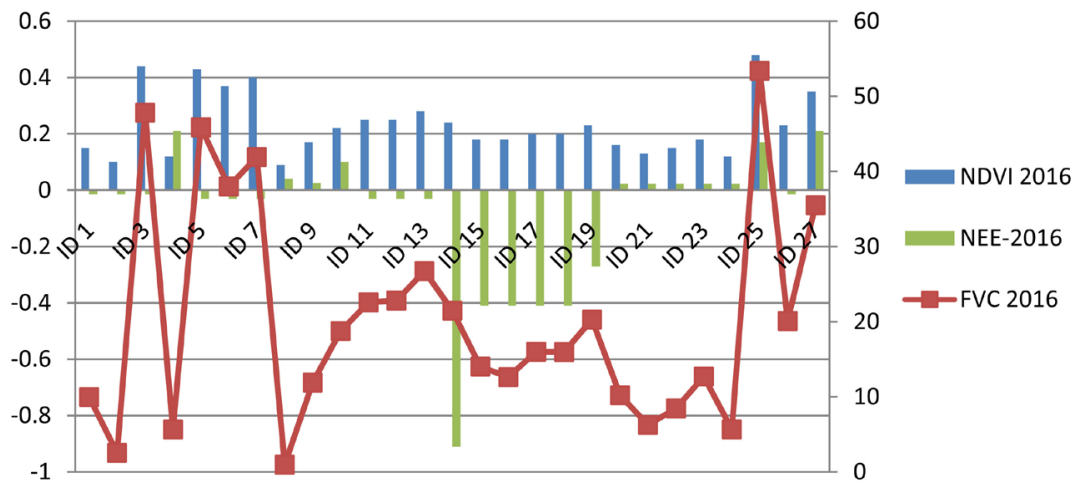

Figure 15. Chart showing comparative account of NDVI, FVC and NEE for year 2016. 


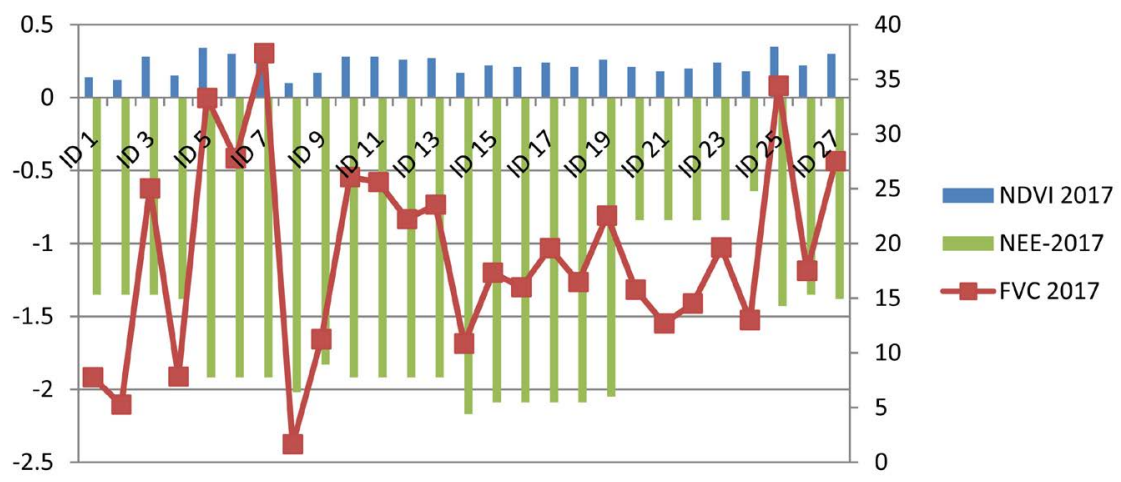

Figure 16. Chart showing comparative account of NDVI, FVC and NEE for year 2017.

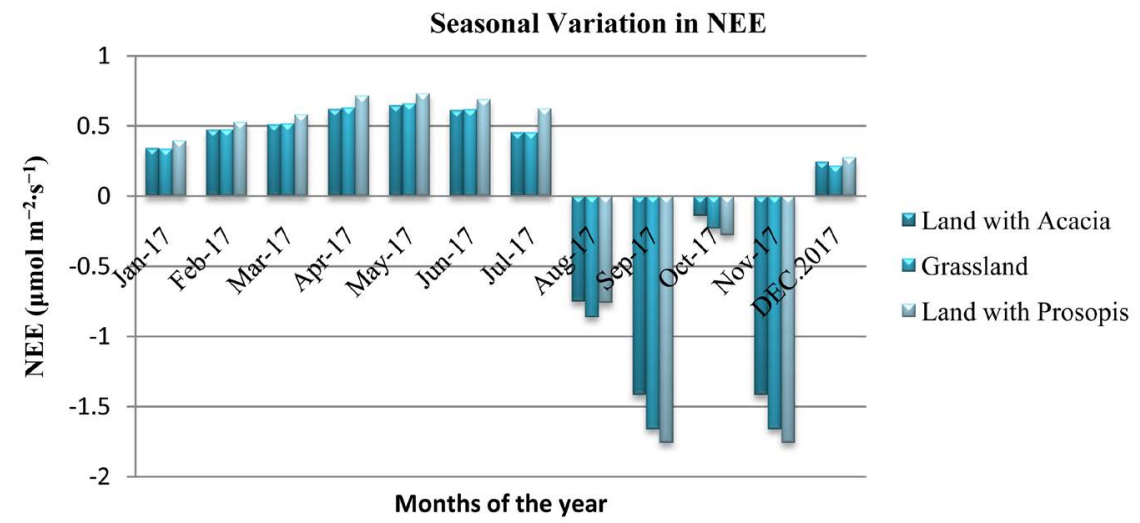

Figure 17. Chart showing seasonal variations in NEE.

year 2017 as compared to the years 2015 and 2016. This indicated that the Ecosystem $\mathrm{CO}_{2}$ exchange rates were strongly influenced by the type of vegetation which was also evident from the NEE values obtained for these categories. NDVI of the Banni grasslands was found to be higher than a threshold of about 0.3 which indicated that grasses were strong enough to drive a substantial portion of the NEE flux and provided improved NEE in comparison to the Prosopis and Acacia. For each category a steady increase with the growing season with a distinct decrease after the peak season was noted. With respect to the NEE values for different vegetational categories, not much difference was observed. Though Prosopis showed extreme higher and lower values ranging from $-1.75 \mu \mathrm{g} / \mathrm{m}^{2}$ to $0.73 \mu \mathrm{g} / \mathrm{m}^{2}$ the cumulative values for NEE was highest for Grasses i.e. -0.5 followed by Acacia and Prosopis; 0.18 and 0.0, respectively proving grasslands to be an effective sink of carbon dioxide sequestration and no contribution of Prosopis for the same (Figure 17). Prosopis showed more negative values of NEE as compared to Acacia during the growth period while it showed more positive values during the summers. This indicated that though Prosopis absorbed a high amount of carbon and acted as a sink during growth period but at the same time released a high amount of carbon and acted as the source of the carbon. This may lead to a decreased capacity of carbon uptake and conversion of this ecosystem into the source of the carbon. 


\section{Conclusion}

This study proved that NEE varies with different plant species and in this study, grasses were found to be the most active sink of the carbon dioxide while Prosopis and Acacia acted as weaker sinks. The ecosystem of Banni acted as the source of $\mathrm{C}$ for almost an entire year in the absence of grasses (i.e. during January to June) while as a sink during the growth period of grasses (i.e. during July to December). Furthermore, application of spatial approach provided consistent and systematic observations for monitoring plant species of Banni grasslands and NEE data at fine temporal resolutions which helped in comprehensive understanding.

\section{Acknowledgements}

The authors are highly indebted to the Department of Science and Technology (DST) for providing financial support to carry out this study.

\section{Conflicts of Interest}

The authors declare no conflicts of interest regarding the publication of this paper.

\section{References}

[1] Matthews, H.D., Weaver, A.J. and Meissner, K.J. (2005) Terrestrial Carbon Cycle Dynamics under Recent and Future Climate Change. Journal of Climate, 18, 16091628. https://doi.org/10.1175/JCLI3359.1

[2] Sinninghe Damsté, J.S., Verschuren, D., Ossebaar, J., Blokker, J., van Houten, R., van der Meer, M.T.J., Plessen, B. and Schouten, S.A. (2011) 25,000-Year Record of Climate-induced Changes in Lowland Vegetation of Eastern Equatorial Africa Revealed by the Stable Carbon-Isotopic Composition of Fossil Plant Leaf Waxes. Earth and Planetary Science Letters, 302, 236-246. https://doi.org/10.1016/j.epsl.2010.12.025

[3] Green, J.K., Seneviratne, S.I., Berg, A.M., Findell, K.L., Hagemann, S., Lawrence, D.M. and Gentine, P. (2019) Large Influence of Soil Moisture on Long-Term Terrestrial Carbon Uptake. Nature, 565, 476-479. https://doi.org/10.1038/s41586-018-0848-x

[4] CEC (Commission for Environmental Cooperation) (2014) Estimating Carbon Dynamics in the Tropical Semi-Deciduous Forest of the Yucatan Peninsula. Commission for Environmental Cooperation, Montreal, 46.

[5] Kramer, K., Leinonen, I., Bartelink, H.H., Berbigier, P., Borghetti, M., Bernhofer, C., et al. (2002) Evaluation of Six Process-Based Forest Growth Models Using Eddy-Covariance Measurements of $\mathrm{CO}_{2}$ and $\mathrm{H}_{2} \mathrm{O}$ Fluxes at Six Forest Sites in Europe. Global Change Biology, 8, 213-230. https://doi.org/10.1046/j.1365-2486.2002.00471.x

[6] Wood, D.A. (2021) Net Ecosystem Carbon Exchange Prediction and Insightful Data Mining with an Optimized Data-Matching Algorithm. Ecological Indicators, 124, Article ID: 107426. https://doi.org/10.1016/j.ecolind.2021.107426

[7] Liang, W., Zhang, W., Jin, Z., Yan, J., Lü, Y., Wang, S., et al. (2020) Estimation of Global Grassland Net Ecosystem Carbon Exchange Using a Model Tree En- 
semble Approach. Journal of Geophysical Research: Biogeosciences, 125, Article ID: e2019JG005034. https://doi.org/10.1029/2019JG005034

[8] Whittaker, R.H. and Likens, G.E. (1975) The Biosphere and Man. In: Leith, H. and Whittaker, R.H., Eds., Primary Productivity and the Biosphere, Vol. 14, SpringerVerlag, Berlin, 305-328. https://doi.org/10.1007/978-3-642-80913-2_15

[9] Knapp, A.K. and Smith, M.D. (2001) Variation among Biomes in Temporal Dynamics of Aboveground Primary Production. Science, 291, 481-484. https://doi.org/10.1126/science.291.5503.481

[10] Huxman, T.E., Cable, J.M., Ignace, D.D., Eilts, J.A., English, N.B., Weltzin, J. and Williams, D.G. (2004) Response of Net Ecosystem Gas Exchange to a Simulated Precipitation Pulse in Semi-Arid Grassland: The Role of Native versus Non-Native Grasses and Soil Texture. Oecologia, 141, 295-305.

https://doi.org/10.1007/s00442-003-1389-y

[11] Huxman, T.E., Snyder, K.A., Tissue, D., Joshua Leffler, A., Ogle, K., Pockman, W.T., et al. (2004) Precipitation Pulses and Carbon Fluxes in Semiarid and Arid Ecosystems. Oecologia, 141, 254-268. https://doi.org/10.1007/s00442-004-1682-4

[12] Novick, K.A., Oishi, A.C., Ward, E.J., Siqueira, M.B.S., Juang, J.-Y. and Stoy, P.C. (2015) On the Difference in the Net Ecosystem Exchange of $\mathrm{CO}_{2}$ between Deciduous and Evergreen Forests in the Southeastern United States. Global Change Biology, 21, 827-842. https://doi.org/10.1111/gcb.12723

[13] Grace, J., San José, J., Meir, P., Miranda, H.S. and Montes, R.A. (2006) Productivity and Carbon Fluxes of Tropical Savannas. Journal of Biogeography, 33, 387-400.

https://doi.org/10.1111/j.1365-2699.2005.01448.x

[14] Arora, V.K. and Boer, G.J. (2010) Uncertainties in the 20th Century Carbon Budget Associated with Land Use Change. Global Change Biology, 16, 3327-3348. https://doi.org/10.1111/j.1365-2486.2010.02202.x

[15] Turner, D.P., Ollinger, S.V. and Kimball, J.S. (2004) Integrating Remote Sensing and Ecosystem Process Models for Landscape- to Regional-Scale Analysis of the Carbon Cycle. BioScience, 54, 573-584. https://doi.org/10.1641/0006-3568(2004)054[0573:IRSAEP]2.0.CO;2

[16] Pielke Sr., R.A., Walko, R.L., Steyaert, L.T., Vidale, P.L., Liston, G.E., Lyons, W.A., et al. (1998) The Influence of 15 Anthropogenic Landscape Changes on Weather in South Florida. Monthly Weather Review, 127, 1663-1673. https://doi.org/10.1175/1520-0493(1999)127\%3C1663:TIOALC\%3E2.0.CO;2

[17] Gregory, P.A., George, V.N.P., Joseph, M., David, E.K., John, K.C. and James, J. (2010) High Resolution Forest Carbon Stocks and Emissions in the Amazon. Proceedings of the National Academy of Sciences of the United States of America, 107, 16738-16742. https://doi.org/10.1073/pnas.1004875107

[18] Raymond Hunt Jr., E., Fahnestock, J.T., Kelly, R.D., Welker, J.M., Reiners, W.A. and Smith, W.K. (2002) Carbon Sequestration from Remotely-Sensed NDVI and Net Ecosystem Exchange. In: Muttiah, R.S., Ed., From Laboratory Spectroscopy to Remotely Sensed Spectra of Terrestrial Ecosystems, Springer, Dordrecht, 161-174. https://doi.org/10.1007/978-94-017-1620-8_8

[19] Yan, W., Hu, Z., Zhao, Y., Zhang, X., Fan, Y., Shi, P., et al. (2015) Modeling Net Ecosystem Carbon Exchange of Alpine Grasslands with a Satellite-Driven Model. PLoS ONE, 10, e0122486. https://doi.org/10.1371/journal.pone.0122486

[20] Clark, D.A., Brown, S., Kicklighter, D.W., Chambers, J.Q., Thomlinson, J.R. and Ni, J. (2001) Measuring Net Primary Production in Forests: Concepts and Field Methods. Ecological Applications, 11, 356-370. 
https://doi.org/10.1890/1051-0761(2001)011[0356:MNPPIF]2.0.CO;2

[21] Baldocchi, D.D. and Wilson, K.B. (2001) Modeling $\mathrm{CO}_{2}$ and Water Vapor Exchange of a Temperate Broadleaved Forest across Hourly to Decadal Time Scales. Ecological Modelling, 142, 155-184. https://doi.org/10.1016/S0304-3800(01)00287-3

[22] Powell, T.L., Bracho, R., Li, J.H., Dore, S., Hinkle, C.R. and Drake, B.G. (2006) Environmental Controls over Net Ecosystem Carbon Exchange of Scrub Oak in Central Florida. Agriculture and Forest Meteorology, 141, 19-34.

https://doi.org/10.1016/j.agrformet.2006.09.002

[23] Crawford, B. and Christen, A. (2014) Spatial Variability of Carbon Dioxide in the Urban Canopy Layer and Implications of Flux Measurements. Atmospheric Environment, 98, 308-322. https://doi.org/10.1016/j.atmosenv.2014.08.052

[24] Osmond, B., Ananyev, G., Berry, J., Langdon, C., Kolber, Z., Lin, G.H., et al. (2004) Changing the Way We Think about Global Change Research: Scaling up in Experimental Ecosystem Science. Global Change Biology, 10, 393-407.

https://doi.org/10.1111/j.1529-8817.2003.00747.x

[25] Schulze, E.D., Valentini, R. and Bouriaud, O. (2021) The Role of Net Ecosystem Productivity and of Inventories in Climate Change Research: The Need for "Net Ecosystem Productivity with Harvest”, NEPH. Forest Ecosystems, 8, Article No. 15. https://doi.org/10.1186/s40663-021-00294-Z

[26] Livingston, G.P. and Hutchinson, G.L. (1995) Enclosure-Based Measurement of Trace Gas Exchange: Applications and Sources of Error. In: Matson, P.A. and Harriss, R.C., Eds., Biogenic Trace Gases. Measuring Emissions from Soil and Water, Blackwell Science Ltd, Oxford, 14-51.

[27] Welles, J.M., Demetriades-Shah, T.H. and McDermitt, D.K. (2001) Considerations for Measuring Ground $\mathrm{CO}_{2}$ Effluxes with Chambers. Chemical Geology, 177, 3-13. https://doi.org/10.1016/S0009-2541(00)00388-0

[28] Davidson, E.A., Savage, K., Verchot, L.V. and Navarro, R. (2002) Minimizing Artifacts and Biases in Chamber-Based Measurements of Soil Respiration. Agriculture and Forest Meteorology, 113, 21-37. https://doi.org/10.1016/S0168-1923(02)00100-4

[29] Gitelson, A.A., Viña, A., Verma, S.B., Rundquist, D.C., Arkebauer, T.J., Keydan, G., et al. (2006) Relationship between Gross Primary Production and Chlorophyll Content in Crops: Implications for the Synoptic Monitoring of Vegetation Productivity. Journal of Geophysical Research, 111, Article No. D08S11. https://doi.org/10.1029/2005JD006017

[30] Gitelson, A.A., Peng, Y., Masek, J.G., Rundquist, D.C., Verma, S.V., Suyker, A., et al. (2012) Remote Estimation of Crop Gross Primary Production with Landsat data. Remote Sensing of Environment, 121, 404-414.

https://doi.org/10.1016/j.rse.2012.02.017

[31] Xiao, J., Zhuang, Q., Law, B.E., Chen, J., Baldocchi, D.D., Cook, D.R., et al. (2010) A Continuous Measure of Gross Primary Production for the Conterminous United States Derived from MODIS and AmeriFlux Data. Remote Sensing of Environment, 114, 576-591. https://doi.org/10.1016/j.rse.2009.10.013

[32] Senay, G.B., Velpuri, N.M., Bohms, S., Budde, M., Young, C., Rowland, J., et al. (2015) Drought Monitoring and Assessment: Remote Sensing and Modeling Approaches for the Famine Early Warning Systems Network. In: Shroder, J.F., Paron, P. and Di Baldassarre, G., Eds., Hydro-Meteorological Hazards, Risks and Disasters, Elsevier, Amsterdam, 233-262. https://doi.org/10.1016/B978-0-12-394846-5.00009-6

[33] Stabler, L.B., Martin, C.A. and Brazel, A.J. (2005) Microclimates in a Desert City 
Were Related to Land Use and Vegetation Index. Urban Forestry and Urban Greening, 3, 137-147. https://doi.org/10.1016/j.ufug.2004.11.001

[34] Gitelson, A.A. (2004) Wide Dynamic Range Vegetation Index for Remote Quantification of Biophysical Characteristics of Vegetation. Journal of Plant Physiology, 161, 165-173. https://doi.org/10.1078/0176-1617-01176

[35] Jiménez-Muñoz, J.C., Sobrino, J.A., Plaza, A., Guanter, L., Moreno, J. and Martinez, P. (2009) Comparison between Fractional Vegetation Cover Retrievals from Vegetation Indices and Spectral Mixture Analysis: Case Study of PROBA/CHRIS Data over an Agricultural Area. Sensors, 9, 768-793. https://doi.org/10.3390/s90200768

[36] Salimi Kouchi, H., Sahebi, M., Abkar, A.A. and Valadan Zoej, M.J. (2010) Fractional Vegetation Cover Estimation in Urban Environments. International Archives of the Photogrammetry, Remote Sensing and Spatial Information Sciences-ISPRS Archives, XL-1/W3, 357-360. https://doi.org/10.5194/isprsarchives-XL-1-W3-357-2013

[37] Purevdor, J.T.S., Tateishi, R., Ishiyama, T. and Honda, Y. (1998) Relationships between Percent Vegetation Cover and Vegetation Indices. International Journal of Remote Sensing, 19, 3519-3535. https://doi.org/10.1080/014311698213795

[38] Jing, X., Yao, W., Wang, J. and Song, X.-Y. (2010) A Study on the Relationship between Dynamic Change of Vegetation Coverage and Precipitation in Beijing's Mountainous Areas during the Last 20 Years. Mathematical and Computer Modelling, 54, 1079-1085. https://doi.org/10.1016/j.mcm.2010.11.038

[39] Godínez-Alvarez, H., Herrick, J.E., Mattocks, M., Toledo, D. and Van Zee, J. (2009) Comparison of Three Vegetation Monitoring Methods: Their Relative Utility for Ecological Assessment and Monitoring. Ecological Indicators, 9, 1001-1008. https://doi.org/10.1016/j.ecolind.2008.11.011

[40] Steffen, W. (2003) The IGBP Terrestrial Transects: Tools for Resource Management and Global Change Research at the Regional Scale. In: Ringrose, S. and Chanda, R. Eds., Towards Sustainable Managementin the Kalahari Region: Some Essential Background and Critical Issues, University of Botswana, Gaborone, 1-11.

[41] Shoshany, M., Kutiel, P. and Lavee, H. (1996) Monitoring Temporal Vegetation cover Changes in Mediterranean and Arid Ecosystems Using a Remote Sensing Technique: Case Study of the Judean Mountain and the Judean Desert. Journal of Arid Environment, 33, 9-21. https://doi.org/10.1006/jare.1996.0042

[42] Brazel, A.J. and Nickling, W.G. (1987) Dust Storms and Their Relation to Moisture in the Sonoran-Mojave Desert Region of the South-Western United States. Journal of Environmental Management, 24, 279-291.

[43] Liang, X.Z., Xu, M., Gao, W., Reddy, K.R., Kunkel, K., Schmoldt, D.L., et al. (2012) Physical Modeling of U.S. Cotton Yields and Climate Stresses during 1979 to 2005. Agronomy Journal, 104, 675-683. https://doi.org/10.2134/agronj2011.0251

[44] National Research Council (1986) Population Growth and Economic Development: Policy Questions. National Academy Press, Washington DC.

[45] Bharara, L.P. (1987) Preliminary Report on Socio-Economic Survey of Banni Area, Kutch District (Gujarat). Central Arid Zone Research Institute, Jodhpur, 44.

[46] Ferroukhi, L. (1994) An Ecological Groundwater Harvesting under Threat. A Case Study of the Banni Pastoralist's Knowledge in the Grasslands of the Kachchh District, Gujarat State, India. MSc Thesis, Swedish University of Agriculture, Uppsala.

[47] Tong, S., Zhang, J., Ha, S., Lai, Q. and Ma, Q. (2016) Dynamics of Fractional Vegetation Coverage and Its Relationship with Climate and Human Activities in Inner Mongolia, China. Remote Sensing, 8, Article No. 776.

https://doi.org/10.3390/rs8090776 
[48] Wylie, B.K., Meyer, D.J., Tieszen, L.L. and Mannel, S. (2002) Satellite Mapping of Surface Biophysical Parameters at the Biome Scale over the North American Grasslands. A Case Study. Remote Sensing of Environment, 79, 266-278. https://doi.org/10.1016/S0034-4257(01)00278-4

[49] Boelman, N.T., Stieglitz, M., Rueth, H., Sommerkorn, M., Griffin, K.L., Shaver, G.R., et al. (2003) Response of NDVI, Biomass, and Ecosystem Gas Exchange to Long-Term Warming and Fertilization in Wet Sedge Tundra. Oecologia, 135, 414-421. https://doi.org/10.1007/s00442-003-1198-3

[50] Chladil, M.A. and Nuñez, M. (1995) Assessing Grassland Moisture and Biomass in Tasmania. The Application of Remote Sensing and Empirical Models for a Cloudy Environment. International Journal of Wildland Fire, 5, 165-171. https://doi.org/10.1071/WF9950165

[51] Seen, D.L., Mougin, E., Rambal, S., Gaston, A. and Hiernaux, P. (1995) A Regional Sahelian Grassland Model to Be Coupled with Multispectral Satellite Data. II: Toward the Control of Its Simulations by Remote Sensing Indices. Remote Sensing of Environment, 52, 194-206. https://doi.org/10.1016/0034-4257(94)00127-9

[52] Gower, S.T., Kucharik, C.J. and Norman, J.M. (1999) Direct and Indirect Estimation of Leaf Area Index FAPAR, and Net Primary Production of Terrestrial Ecosystems. Remote Sensing of Environment, 70, 29-51. https://doi.org/10.1016/S0034-4257(99)00056-5

[53] Hall, F.G., Townshend, J.R. and Engman, E.T. (1995) Status of Remote Sensing Algorithms for Estimation of Land Surface State Parameters. Remote Sensing of Environment, 51, 138-156. https://doi.org/10.1016/0034-4257(94)00071-T

[54] Running, S.W. and Nemani, R.R. (1988) Relating Seasonal Patterns of the AVHRR Vegetation Index to Simulated Photosynthesis and Transpiration of Forests in Different Climates. Remote Sensing of Environment, 24, 347-367. https://doi.org/10.1016/0034-4257(88)90034-X

[55] Slayback, D.A., Pinzon, J.E., Los, S.O. and Tucker, C.J. (2003) Northern Hemisphere Photosynthetic Trends 1982-99. Global Change Biology, 9, 1-15. https://doi.org/10.1046/j.1365-2486.2003.00507.x

[56] Wylie, B.K., Johnson, D.A., Laca, E., Saliendra, N.Z., Gilmanov, T.G., Reed, B.C., et al. (2003) Calibration of Remotely Sensed, Coarse Resolution NDVI to $\mathrm{CO}_{2}$ Fluxes in a Sagebrush-Steppe Ecosystem. Remote Sensing of Environment, 85, 243-255. https://doi.org/10.1016/S0034-4257(03)00004-X

[57] Frank, A.B. and Karn, J.F. (2003) Vegetation Indices, $\mathrm{CO}_{2}$ Flux, and Biomass for Northern Plains Grasslands. Journal of Range Management, 56, 382-387. https://doi.org/10.2307/4004043

[58] Korrensalo, A., Mehtätalo, L., Alekseychik, P., Uljas, S., Mammarella, I., Vesala, T. et al. (2020) Varying Vegetation Composition, Respiration and Photosynthesis Decrease Temporal Variability of the $\mathrm{CO}_{2}$ Sink in a Boreal Bog. Ecosystems, 23, 842-858. https://doi.org/10.1007/s10021-019-00434-1

[59] Falge, E., Baldocchi, D., Tenhunen, J., Aubinet, M., Bakwin, P., Berbigier, P., et al. (2002) Seasonality of Ecosystem Respiration and Gross Primary Production as Derived from FLUXNET Measurements. Agriculture and Forest Meteorology, 113, 53-74. https://doi.org/10.1016/S0168-1923(02)00102-8

[60] Falge, E., Tenhunen, J., Baldocchi, D., Aubinet, M., Bakwin, P., Bernhofer, C., et al. (2002) Phase and Amplitude of Ecosystem Carbon Release and Uptake Potential as Derived from FLUXNET Measurements. Agriculture and Forest Meteorology, 113 , 75-95. https://doi.org/10.1016/S0168-1923(02)00103-X 
[61] Singh, N., Parida, B.R., Charakborty, J.S. and Patel, N.R. (2019) Net Ecosystem Exchange of $\mathrm{CO}_{2}$ in Deciduous Pine Forest of Lower Western Himalaya, India. Resources, 8, Article No. 98. https://doi.org/10.3390/resources8020098

[62] Niu, Y., Li, Y., Yun, H., Wang, X., Gong, X., Duan, Y. and Liu, J. (2020) Variations in Diurnal and Seasonal Net Ecosystem Carbon Dioxide Exchange in a Semiarid Sandy Grassland Ecosystem in China's Horqin Sandy Land. Biogeosciences, 17, 63096326. https://doi.org/10.5194/bg-17-6309-2020

[63] Tang, X., Zhou, Y., Li, H., Yao, L., Ding, Z., Ma, M., et al. (2020) Remotely Monitoring Ecosystem Respiration from Various Grasslands along a Large-Scale East-West Transect across Northern China. Carbon Balance Management, 15, Article No. 6. https://doi.org/10.1186/s13021-020-00141-8

[64] Meza, F.J., Montes, C., Bravo-Martínez, F., Serrano-Ortiz, P. and Kowalski, A.S. (2018) Soil Water Content Effects on Net Ecosystem $\mathrm{CO}_{2}$ Exchange and Actual Evapotranspiration in a Mediterranean Semiarid Savanna of Central Chile. Scientific Reports, 8, Article No. 8570. https://doi.org/10.1038/s41598-018-26934-Z 